\title{
EL RÉGIMEN DEL SERVICIO CIVIL: ENFOQUE JURÍDICO
}

\author{
CELÍN ARCE GÓMEZ \\ Oficina Jurídica \\ Universidad Estatal a Distancia, Costa Rica \\ carce@uned.ac.cr
}

\section{RESUMEN}

El servicio civil es el régimen por antonomasia que rige la administración del personal del Estado costarricense. Si bien es cierto que el Estatuto del Servicio Civil regula a los funcionarios del Poder Ejecutivo, no menos cierto es que es el modelo que inspira y guía al resto del Estado en la definición del marco jurídico que ha de regular sus relaciones obrero patronales. El éxito de la Administración Pública y la forma en que se administra el Estado costarricense, con todos sus defectos y virtudes, se debe en mucho al modelo del servicio civil que acogió Costa Rica en la constituyente de 1949. Pretende este artículo dar a conocer los antecedentes de tal régimen, sus características, evolución y el perfil jurídico que a este le ha dado la Sala Constitucional por medio de su jurisprudencia.

PALABRAS CLAVES: SERVICIO CIVIL, ESTADO COSTARRICENSE, ADMINISTRACIÓN PÚBLICA, ASAMBLEA CONSTITUYENTE DE 1949, SALA CONSTITUCIONAL.

\section{ABSTRACT}

The civil service is par excellence the regime governing the personnel management of Costa Rica. While it is true that the Civil Service Statute regulates executive branch officials, no less true that, is the model that inspires and guides the rest of the state in defining the legal framework has to regulate labor-management relations. The success of Public Administration and how it manages the Costa Rican government with all its faults and virtues, owes much to the civil service model that received Costa Rica in the constituency in 1949. This article aims to present the history of that regime, their characteristics, evolution and the same legal profile has given the Constitutional Court through its jurisprudence.

KEYWORDS: CIVIL SERVICE, THE COSTA RICAN STATE, PUBLIC ADMINISTRATION, CONSTITUENT ASSEMBLY OF 1949, THE CONSTITUTIONAL CHAMBER.

\section{INTRODUCCIÓN}

La creación del régimen del servicio civil tiene una trascendencia jurídica y política muy importante en nuestro país, por cuanto vino a cambiar de manera sustancial la forma en que se venía rigiendo las relaciones entre el Estado-patrono y el funcionario público; además de que se convirtió en el modelo a seguir en todo el Estado costarricense al menos en sus principios, fundamentos y filosofía.

Su creación no fue fácil. Fue una lucha de décadas pero al fin se logró culminar dicho proceso con ocasión de la aprobación de la Constitución de 1949, en cuyo seno se originó un debate con posiciones divergentes.

Otro gran paso que se da en su consolidación y desarrollo es la creación de la Sala Constitucional en el año 1989, la que, al interpretar la Constitución como un todo y de manera particular los ar- 
tículos 191 y 192 destinados a regular el Servicio Civil, logra vigorizar dicho régimen actualizándolo y protegiendo aún más los derechos del empleado público.

No se puede entender el funcionamiento del Estado costarricense a partir de 1949 sin el régimen del servicio civil vivificado con la jurisprudencia constitucional.

A continuación su origen y desarrollo.

\section{Antecedentes inmediatos}

El antecedente jurídico más inmediato del régimen del servicio civil corresponde a la reforma a la Constitución de 1871, mediante la Ley n. ${ }^{\circ} 540$ del 18 de junio de 1946, que reformó el inciso 1) del artículo 109 de la Constitución Política conforme al siguiente texto:

Nombrar y remover libremente a los Secretarios de Estado, a los funcionarios y empleados diplomáticos, a los militares y a los otros que indique el Estatuto Civil de la Función Pública y, con sujeción a las prescripciones de este, a los demás funcionarios y empleados de su dependencia. Para la aprobación o enmienda de dicho Estatuto se necesitará el voto de los dos tercios de la totalidad de los miembros del Poder Legislativo y en él no podrá incluirse como impedimento para la admisión al ejercicio de la función pública, ni como causal de destitución, el hecho de sustentar determinadas ideas de carácter político o social (Constitución Política de Costa Rica).

Esta reforma a la Constitución de 1871, tuvo origen en una moción presentada, en la primera legislatura del Gobierno de Teodoro Picado, por diez Diputados contrarios a su gobierno, con la colaboración muy valiosa del Licenciado don Miguel Brenes quien luego sería miembro de la Asamblea Constituyente de 1949.
El impacto de dicha reforma fue tal que, posteriormente, fue adoptada como base para el establecimiento del Servicio Civil en Costa Rica, de una manera oficial y solemne, por el Partido Unión Nacional, que la incorporó en su Programa de Gobierno al efectuar su inscripción en el Registro Electoral el 21 de noviembre de 1946.

Ciertamente ese Programa dice en lo conducente:

Ningún empleado público podrá ser destituido por razones de orden político... Servicio Civil. El Partido promoverá de inmediato la inamovilidad efectiva de los maestros y profesores. Procurará hacer efectiva la reciente disposición constitucional de creación del Servicio Civil, pero no mediante decretos que hagan de golpe inamovibles a todos los empleados sino organizando, por oposición, sucesivamente, los departamentos de la Administración con personal idóneo y limitado a las necesidades de cada uno de ellos y aplicando la Ley de Servicio Civil en cada caso. El actual sistema de reclutamiento libre de empleados, en realidad hace de los puestos oficiales un patrimonio personal de los gobernantes para premiar a sus amigos y partidarios, haciendo que la eficiencia de los servicios no sea la misma que se obtendría reclutándolos hasta donde fuera posible, sobre bases técnicas o de especialización (Asamblea Legislativa, 1957, p. 130).

Como producto de esta enmienda constitucional se redactó el primer proyecto de Estatuto Civil de la Función Pública cuyo autor lo fue el Lic. Oscar Barahona Streber quien, poco antes, había redactado el Código de Trabajo.

Este proyecto, en su artículo $1^{\circ}$ decía:

El objetivo primordial de esta Ley y de sus reglamentos es establecer una Adminis $\neg$ tración Pública Técnica, eficiente, depurada y económica regulando los dere- 
chos y obligaciones, con ocasión del trabajo, de todos los trabajadores que estén directamente al servicio del Poder Ejecutivo o de las Municipalidades, o de las entidades u organis $\neg$ mos dependientes de o estrechamente relacionados con aquel o con estas.

Mediante otro de sus artículos, se creaba el Instituto Costarricense de Servicio Civil. Posteriormente, la Junta de Gobierno, presidida por don José Figueres, mediante decreto ley, promulgó un Estatuto de Servicio Civil que debió entrar en vigencia en la fecha que determinara la Asamblea Legislativa, lo cual no sucedió ya que esta no llegó a conocerlo.

Agotado este primer esfuerzo, el próximo debate se daría en la Constituyente del 49.

\section{El debate sobre la creación del servicio civil en la Constitución de 1949}

El inciso 2) del artículo 140 de la Constitución le asigna al Presidente de la República y al respectivo Ministro la potestad de: "Nombrar y remover, con sujeción a los requisitos prevenidos por La Ley de Servicio Civil, a los restantes servidores de su dependencia".

En orden cronológico es la primera referencia al servicio civil. A continuación se dan a conocer los orígenes de dicha norma.

\section{La aprobación del inciso 2) del artículo 140}

La moción original dio base para que cada Diputado o fracción se pronunciase a favor o no de la creación del régimen del servicio civil

A favor de la moción se pronuncia inicialmente el Diputado Rafael Carrillo Echeverría miembro de la fracción social demócrata proponente, quien expresó que era un anacronismo que a estas alturas estemos discutiendo en Costa Rica sobre la conveniencia del Servicio Civil si sus principios ya estaban incorporados en la Constitución de 1871. Recordó que la libertad del Presidente para nombrar y remover a los empleados públicos, que preconizaba el Presidente Taft en los Estados Unidos como una condición de la responsabilidad presidencial, produjo graves males a dicho país especialmente en lo que se llamó "el sistema de los despojos" (spoils system) en virtud del cual los cargos públicos se distribuían entre los miembros del partido vencedor en las elecciones.

De ahí que según su criterio:

El nuevo sistema, acorde con la mejor técnica administrativa, ha venido a demostrar que no se necesita la libertad de nombramiento y destitución para exigir la responsabilidad, sino que hay otras maneras de lograrlo: los nombramientos por méritos, el estímulo que significa la posibilidad de los ascensos por servicio eficiente, las medidas disciplinarias, las reglamentaciones financieras de control y auditoría de gastos, las medidas judiciales de orden civil y penal para las responsabilidades de los funcionarios, que son necesarias en un orden jurídico y en un gobierno constitucional (Asamblea Legislativa, 1957, p. 129).

Y concluyó diciendo: "pero no demos un paso atrás en la conquista de la institución del Servicio Civil, para que se diga en el futuro que los Constituyentes de 1949 no supimos interpretar una de las más caras esperanzas de los costarricenses." (Asamblea, 1957, p. 130).

Otro que se pronunció a favor de la creación del régimen fue el Diputado electo por el Partido Unión Nacional, Otón Acosta Jiménez, quien declaró que le daría con mucho gusto el voto a la moción del Social Demócrata, porque pensaba que el intento de llevar a la Constitución una norma que le garantizara a los empleados 
públicos su inamovilidad, salvo por motivos justificados, acogía un anhelo popular, que vino nutriendo las filas de la antigua Oposición a través de sus años de lucha. Según su criterio la inexistencia de una Ley de Servicio Civil en Costa Rica había sido uno de los factores principales de la corrupción en la Administración Pública. Ese espectáculo deplorable de los empleados públicos plegados al partido político en el poder por temor a la cesantía, debía desaparecer de nuestro medio. Los países más adelantados del mundo, habían establecido la Ley de Servicio Civil, como Inglaterra (que echó las bases de esta ley desde tiempos del Ministro Glaxon), Uruguay, Estados Unidos, Colombia, entre otros. Además, consideraba que, por encima de las pasiones políticas, se deban salvar los principios.

Concluyó manifestando que: "por esa razón no puede negarle su voto a la moción en debate, la cual, además, recoge un clamor popular, para acabar de una vez por todas con el espectáculo bochornoso del político que recoge adhesiones en las oficinas públicas, con la amenaza del despido para aquellos empleados que se niegan a hacerlo" (Asamblea Legislativa, 1957, p. 131).

Don Otilio Ulate Blanco en su condición de dirigente político y su fracción del Partido Unión Nacional se opusieron originalmente a la moción social demócrata, no por no creer en el régimen, sino por razones prácticas inmediatas comprensibles en ese momento.

Por medio de su diputado Ricardo Esquivel Fernández, definió su postura y la de su partido indicando que temía que si esa moción pasaba, no se podría reajustar el presupuesto a las necesidades reales del país cuando asumiera el gobierno Don Otilio Ulate el 8 de noviembre de 1949 y que para nadie era un secreto el desarrollo enorme de la burocracia bajo la Junta de Gobierno presidida por don José Figueres Ferrer, por lo que resultaba de imperiosa necesidad ajustar el presupuesto a la realidad económica del país, la cual sería una de las tareas fundamentales que tendría que asumir de inmediato el próximo gobierno.

El diputado informó en la Asamblea que don Otilio Ulate le dijo que él no era enemigo de la Ley de Servicio Civil, todo lo contrario, que presentará a la Asamblea Legislativa un proyecto de ley de Servicio Civil.

Se refirió el Lic. Esquivel Fernández a los inconvenientes de estructurar una ley de Servicio Civil en los actuales momentos, "porque significaría que el señor Ulate tendría que gobernar con empleados públicos que no son sus partidarios y amigos. Tendría que gobernar con miembros del partido que está en el poder -el Social Demócrata-y con simpatizantes del señor Figueres" (Asamblea, 1957, p. 131).

La anterior preocupación de don Otilio, fue lo que dio base para que se aprobase el transitorio al artículo 140 de la Constitución, a iniciativa de la misma fracción Social demócrata y que dice:

Transitorio.- La Ley de Servicio Civil no entrará en vigencia antes del ocho de noviembre de mil novecientos cincuenta, ni después del primero de junio de mil novecientos cincuenta y tres, según lo acuerde la Asamblea Legislativa. Esa ley podrá, además, disponer que sus normas se apliquen gradualmente a los diversos departamentos de la Administración Pública; en todo caso, dicha ley deberá proteger a la totalidad de los servidores públicos incluidos en el inciso 2) de este artículo, a más tardar el ocho de noviembre de mil novecientos cincuenta y nueve.

Mientras no entre en vigencia la Ley de Servicio Civil, el Presidente de la República y el respectivo Ministro de Gobierno podrán nombrar y remover libremente a todos los funcionarios de su dependencia, incluso a los Directores y Gerentes de las Instituciones Autónomas y a los integrantes de las Juntas 
u organismos oficiales, cuyos nombramientos hubieren sido hechos con anterioridad a la fecha de vigencia de esta Constitución, aun cuando tales designaciones lo fueren por período fijo (Asamblea, 1957, p. 626).

En virtud de este transitorio el derecho de inamovilidad del servidor público no entraría en vigencia hasta la aprobación de la Ley de Servicio Civil, la cual se dio el 30 de mayo de 1953, por lo que hasta esa fecha el Presidente de la República y su Ministros tendrían libertad para despedir a los empleados públicos.

Por tal razón hubo voces que se expresaron en contra de la aprobación del transitorio puesto que se estaría introduciendo una discriminación en contra de los empleados públicos del momento.

Es el caso del Diputado Fernando Volio Sancho, electo por el Partido Unión Nacional, quien manifestó que de aprobarse el artículo transitorio dicho, no solo se rompería la armonía que había predominado en esa Asamblea sino que se producirían graves perturbaciones políticas en el país, puesto que se deseaba dejar la puerta abierta para echar a la calle a los servidores públicos como si se tratara de los delincuentes del régimen anterior y sin que se les pagase las prestaciones legales a que tenían legítimo derecho, como trabajadores que eran, por lo que consideraba esta medida como atentatoria y arbitraria.

Además, según su criterio, la medida vendría a constituir un pésimo precedente con respecto a las Instituciones Autónomas, ya que se permite al Ejecutivo meter la mano en el sistema de estas, comprometiendo su estabilidad. Siempre en Costa Rica ha habido el propósito de respetar la autonomía de tales instituciones y ese propósito se ha cumplido: "terminó diciendo que si la Asamblea persiste en su empeño de llevar adelante la moción, él salva su responsabilidad, por las consecuencias correspondientes" (Asamblea, 1957, p. 549).
Otro Diputado que también se manifestó en desacuerdo con el transitorio fue el Lic. Celso Gamboa Rodríguez del Partido Constitucional (Asamblea, 1957, p. 549), quien veía una manifiesta contradicción en el hecho de que la Asamblea acababa de aprobar un capítulo sobre Garantías Sociales, uno de cuyos artículos establecía el pago de una indemnización para los trabajadores despedidos sin justa causa y ahora mediante una disposición transitoria, se venía a hacer nulos esos derechos que se habían consagrado.

El Lic. Fernando Baudrit Solera quien además de constituyente fungía como Rector de la recién creada Universidad de Costa Rica se pronunció en contra del transitorio, aduciendo que si dicha disposición iba a ser extensiva a la Universidad, "no tenga cuidado alguno el futuro Ministro de Educación; allí le quedará mi puesto de Rector sin preavisos ni cesantías si en la Universidad ha de meter sus manos lo oficial, nada tendría que hacer yo en la Institución" (Asamblea, 1957, p. 549).

Don Rodrigo Facio, (Asamblea, 1957, p. 553), también se pronunció en contra por cuanto dicho transitorio violaba principios sociales y de autonomía de alta importancia, por ser un mal precedente que le echaba a la Asamblea una sombra de duda y todo para resolver una situación que la próxima Asamblea Legislativa debía resolver mediante simple legislación ordinaria.

El Diputado Fernando Founier Acuña del Partido Social Demócrata se unió a este grupo de adversarios negando el voto al transitorio por razones de principio ya que le prometieron al pueblo de Costa Rica respetar los derechos de los servidores públicos pero ahora se pretendía introducirle a la Constitución un transitorio casuístico con el propósito de vulnerar los derechos legítimos de los empleados de la Administración Pública por lo que tampoco quería que se iniciara la próxima administración con despidos en masa de 
servidores fieles y abnegados. "El transitorio se prestará para que el Ejecutivo intervenga en la marcha de las instituciones autónomas en una forma en que ni siquiera se atrevió a hacerlo Álvaro Bonilla" (Asamblea, 1957, p. 553).

Luis Alberto Monge Álvarez, también del Partido Social Demócrata, se opuso al transitorio porque con este se les estaba señalando a los empleados como si fueran delincuentes. No otra cosa se estaba haciendo al declararlos en interinidad y negarles sus prestaciones legales. Añadió que gobiernos inescrupulosos, como los de Calderón y Picado, no habían llegado hasta el extremo de meter sus manos en las instituciones autónomas, que mal que bien fueron respetadas. También señaló que en Costa Rica se había dado una tradición de respeto hacia esas instituciones pero ahora la Asamblea, mediante la aprobación de un transitorio, facultaba al Poder Ejecutivo para intervenir impunemente en la marcha y organización de tales instituciones. Terminó diciendo que pensaba que la Asamblea ha dado uno de sus pasos más graves, no solo por cuanto se lesionan derechos de trabajadores, sino por cuanto se comete la injusticia con un grupo de ciudadanos que no se han doblegado ante determinados círculos económicos y politiqueros (Asamblea, 1957, p. 565).

Frente a dicha oposición y alegatos el Diputado Otón Acosta Jiménez insistió en el espíritu e intención del transitorio enfatizando sobre la idea del aumento enorme de la burocracia durante el régimen actual, ya que la Junta de Gobierno se había caracterizado por la creación permanente de nuevas instituciones que no se ajustaban a la realidad nacional y refirió que la situación fiscal que confronta el país era angustiosa.

Por ello la intención de que el próximo gobierno pudiera hacerle frente a ese problema, fue los que los motivó a la presentación del artículo transitorio en debate, más no el propósito de lanzar a nadie a la calle.
El Gobierno próximo, a no dudarlo, se vería obligado a suprimir una serie de esas instituciones que resultaban innecesarias. "Sin embargo, votará el transitorio propuesto siempre y cuando a ningún servidor público se le prive de sus prestaciones legales a las que tiene derecho. Si el transitorio no se modifica en ese sentido, le negará su voto" (Asamblea, 1957, p. 555).

El Diputado Joaquín Monge Ramírez, del Partido Unión Nacional, insistió en los buenos propósitos del transitorio y pensando en los intereses del próximo gobierno de don Otilio Ulate, alegando que si no se mantenía el transitorio, don Otilio Ulate no podría ajustar su gestión administrativa a lo ya acordado en el capítulo de presupuesto. No habría despidos injustificados en masa, sino supresión de todos los departamentos innecesarios. La realidad es que existían muchas juntas autónomas; la del Ferrocarril al Pacífico, la de la Fábrica Nacional de Licores, entre otras. Terminó diciendo "que no era justo pagar prestaciones legales a quienes han desempeñado puestos innecesarios" (Asamblea, 1957, p. 565).

En resumen, el transitorio se logra aprobar pero con la única intención de permitirle al futuro Gobierno de don Otilio Ulate acometer una reorganización en la Administración Pública, que se estimaba urgente y como único medio para equilibrar el elevado presupuesto de la administración el que, además, le permitiría a ese próximo gobierno la nivelación del presupuesto y le daría al señor Ulate libertad para gobernar.

\section{La creación del capítulo sobre}

El Servicio Civil (artículos 191 a 193)

Una vez aprobada la norma del artículo 140 y su transitorio, la fracción Social Demócrata presentó moción para que fuese creado un nuevo Capítulo en la Constitución sobre Servicio Civil, que constara de los siguientes artículos: 
1. Un estatuto de servicio Civil regulará las relaciones entre el Estado y los servidores públicos, con el propósito de garantizar la eficiencia de los servicios, los cuales serán desempeñados con un criterio técnico y por el personal estrictamente necesario.

2. Con las excepciones que esta Constitución y el Estatuto de Servicio Civil determinen, los servidores públicos serán nombrados a base de idoneidad comprobada y solo podrán ser removidos de sus puestos por las causales de despido justificado que expresa la legislación de Trabajo, o en el caso de reducción forzosa de servicios, ya sea por falta absoluta de fondos o para conseguir una más eficaz y económica organización de los mismos.

Cuando no les esté vedado por esta Constitución, los servidores públicos pueden ejercer actividades electorales, excepto durante las horas de trabajo, y no podrán ser perjudicados por su independencia política.

3. Toda reforma el Estatuto de Servicio Civil requerirá la aprobación de las dos terceras partes del total de los miembros de la Asamblea Legislativa. (Asamblea, 1957, p. 474).

El Representante de dicha fracción Rafael Carrillo Echeverría explicó los propósitos de la moción que proponían, manifestando que era ya una realidad de esa Asamblea que el Servicio Civil se crearía en Costa Rica en un futuro no muy lejano, con lo cual se llenaría una aspiración largamente sentida en el país y que al estatuto de la función pública se llegaría gradualmente, de acuerdo con lo aprobado por la Asamblea. Aclaró que la institución del Servicio Civil en nada iba a afectar los planes de reorganización administrativa del próximo gobierno, ya que la ley de Servicio Civil, en virtud del transitorio aprobado y que reseñamos, solo empezaría a entrar en vigor a partir de noviembre de 1950. Añadió después que el extenso articulado que traía el Proyecto del 49 sobre esta materia, lo habían reducido a lo estrictamente indispensable, en vista del poco tiempo que le queda a la Asamblea. En el nuevo proyecto presentado tan solo se han consignado, en una forma condensada, los postulados esenciales del estatuto de la función pública.

Su compañero de fracción Fernando Fournier Acuña complementó los alcances de la creación del nuevo capítulo sobre Servicio Civil aclarando que se habían concretado a presentar aquellos principios imprescindibles sobre Servicio Civil, en vista de la premura del tiempo e insistió que el Transitorio aprobado, cuando se discutieron las atribuciones del Presidente de la República, en ninguna forma con la aprobación del presente capítulo se entrabaría la reorganización que planeaba el próximo gobierno, ya que expresamente se estableció que la ley de servicio civil no podría entrar a surtir sus efectos antes de noviembre de 1950. “Es decir, al próximo gobierno le queda más de un año para proceder a su tarea de reorganización administrativa" (Asamblea, 1957, p. 475) concluyó.

Así las cosas sometida a votación la moción Social Demócrata para crear en la Constitución un nuevo título que se llamaría "El Servicio Civil", fue aprobada en la sesión 167 del 14 de octubre de 1949.

Seguidamente se comenzó a discutir el grupo de mociones de la misma fracción Social Demócrata, sobre el Servicio Civil, siendo la primera la referida a lo que hoy día es el artículo 191. Dice: "un estatuto de Servicio Civil regulará las relaciones entre el Estado y los servidores públicos, con el propósito de garantizar la eficiencia de los servicios, los cuales serán desempeñados con un criterio técnico y por el personal estrictamente necesario"(Asamblea, 1957, p. 475).

El Licenciado Fernando Fournier Acuña (Asamblea, 1957), indicó que el artículo definía, en cierta forma, el estatuto de Servicio Civil, cuyo 
propósito era el de regular las relaciones entre el Estado y sus servidores públicos, que todas las modernas constituciones de América -como las de Cuba, Panamá y Guatemala- reglamentaban el Servicio Civil hasta el detalle lo que venía demostrar cómo el estatuto de la función pública tenía una gran importancia y que la necesidad no solo se había sentido en Costa Rica sino en los otros países del Continente.

A favor de la creación del servicio civil se pronunció el Diputado Otón Acosta Jiménez (Asamblea, 1957, p. 476), quien adujo que la inexistencia de un estatuto de servicio civil garantizado por preceptos constitucionales, había sido fuente de prácticas viciosas en el país por lo que, si realmente se deseaba acabar con esas prácticas del pasado, era necesario establecer el estatuto de la función pública, debidamente respaldado por la Constitución.

La moción propuesta era esencial, pues definía lo que ha de entenderse por ley de Servicio Civil. Además, venía a constitucionalizar la institución por la que tanto se había clamado en Costa Rica en los últimos años.

De igual forma se pronunció el Representante Manuel Antonio González Herrán del Partido Unión Nacional e hijo del ex presidente Cleto González Víquez (Asamblea, 157, p. 477) quien abogó por la necesidad de establecer la creación del estatuto de Servicio Civil en la Constitución, ya que la simple enunciación del mismo no protegía a los empleados públicos. Agregó que, a su juicio, la frase final del artículo sobraba, el cual bien podría redactarse en los términos siguientes: "un estatuto de servicio Civil regulará las relaciones entre el Estado y los servidores públicos, con el propósito de garantizar la eficiencia de los servicios".

Los proponentes decidieron variar su moción en los términos anteriores, la cual fue aprobada en esa misma sesión.
No obstante la creación del régimen tuvo enemigos en la Constituyente. Tal es el caso del Licenciado Gonzalo Ortiz Martín del Partido Unión Nacional, quien dijo que no votaría la moción Social Demócrata porque no aceptaba el establecimiento de un solo estatuto que cobijara todos los empleados públicos, sin discriminaciones de ninguna clase, porque con ello se crearía más burocratismo. Lo más razonable, según su criterio, era que cada institución, o gremio, o departamento de la Administración, contara con su propio estatuto, tal y como ocurre en la actualidad con los maestros de la República asociados en la ANDE, con lo cual cada uno cuidaría lo suyo, con mucho esmero; vigilaría las categorías, los ascensos y la inversión de los fondos que para la buena marcha y justicia de su institución, pudieran necesitar. En cambio, si iban a establecer un solo estatuto civil, se presentaban una serie de dificultades, a más del gran crecimiento de la burocracia que fatalmente se operaría. Por ello si al menos se dijera en la moción "qué estatutos de servicio civil" regularán las relaciones entre el Estado y sus servidores públicos, le daría su voto, pero no en la forma propuesta (Asamblea, 1957, p. 476).

El Diputado Juan Rafael Arias Bonilla del Partido Constitucional, de manera muy parecida, indicó que se iba a crear una casta privilegiada de empleados públicos cuya destitución sería muy difícil, de acuerdo con el artículo aprobado anteriormente. Es cierto que el estatuto de Servicio Civil, en la forma como se había aprobado amparaba al buen empleado de represalias políticas, pero también es cierto que amparaba exageradamente al mal empleado. Que se respetara y se mantuviera al empleado eficiente, responsable, pero no al malo. Ahora se pretendía que la Ley de Servicio Civil no podría ser modificada sino era por los dos tercios, cuando menos, del total de los miembros de la Asamblea Legislativa. No es posible llevar las cosas hasta ese extremo en perjuicio del país (Asamblea, 1957, p. 477). 
De manera similar el Diputado Edmundo Montealegre del Partido Unión Nacional (Asamblea, 1957, p. 565) preguntó ¿Qué hubiera ocurrido si hubiese existido una Ley de Servicio Civil a la caída del régimen de Picado? Hubiéramos tenido que mantener en sus puestos a una serie de pillos.

Luego se procedió a discutir la moción de lo que hoy día es el artículo 192, que originalmente dice:

Con las excepciones que esta Constitución y el estatuto de servicio Civil determinen, los servidores públicos serán nombrados a base de idoneidad comprobada y solo podrán ser removidos de sus puestos por las causales de despido justificado que expresa la legislación de Trabajo, o en el caso de reducción forzosa de servicios, ya sea por falta absoluta de fondos o para conseguir una más eficaz y económica organización de los mismos (Asamblea, 1957, p. 477).

Nuevamente el Diputado Fernando Fournier Acuña (Asamblea, 1957, p. 477), intervino explicando los alcances del principio de inamovilidad según el cual a ningún empleado se le podrá remover de su puesto, si no es por causales de despido que establece el Código de Trabajo, o en caso de reducción forzosa de servicios por falta absoluta de fondos o para conseguir una más eficaz y económica organización de los mismos, moción que fue aprobada sin mayor discusión.

Finalmente el artículo 3 de la propuesta social demócrata de que "Toda reforma al estatuto de servicio Civil requerirá la aprobación de las dos terceras partes del total de los miembros de la Asamblea Legislativa" (Asamblea, 1957, p. 477), nunca tuvo buen ambiente y fue desechada rápidamente y no se insistió más en el tema.

\section{La promulgación del Estatuto de Servicio Civil}

Una vez que entra en vigencia la Constitución de 1949 y teniendo en cuenta lo indicado en transitorio del artículo 140 de la Constitución según el cual "La Ley de Servicio Civil no entrará en vigencia antes del ocho de noviembre de mil novecientos cincuenta, ni después del primero de junio de mil novecientos cincuenta y tres, según lo acuerde la Asamblea Legislativa"; el Congreso se aboca a cumplir fielmente con el mismo y aprueba el Estatuto de Servicio Civil mediante la Ley No 1581 del 30 de mayo de 1953, que entró en vigencia esa misma fecha.

Para poder cumplir con este transitorio el Poder Ejecutivo integró una Comisión Redactora del proyecto de Estatuto de Servicio Civil con miembros representantes de cada Ministerio y un delegado de la Asociación de Empleados Públicos, la que después de varios meses de trabajo entregó al Poder Ejecutivo su propuesta, a la que el Consejo de Gobierno introdujo algunas reformas previo asesoramiento técnico.

El proyecto de la Comisión fue revisado por el técnico norteamericano Hiram S. Phillips, experto en administración de personal, quien prestaba asesoría en la materia al gobierno de Costa Rica, cuyas observaciones en su mayoría acogió la Comisión.

El proyecto ingresó a la corriente legislativa el 14 de abril de 1953 y fue publicado en la gaceta del 26 de abril de ese año.

La Comisión de Constitución y Legislación, integrada por los Diputados Ricardo Esquivel, Antonio Picado Guerrero y Mario Leiva Quirós el 26 de abril rindió dictamen unánime afirmativo en el entendido de que: "Como se trata de un proyecto redactado y examinado por técnicos en la materia - la cual, a su vez, constituye una novedad dentro de la legislación costarricense- la Comisión se ha abstenido de introducirle reformas 
o de insinuar modificaciones, reservándose, sin embargo, el derecho de sugerirlas en el curso de los debates, si lo estimares necesario" (Asamblea expediente, p. 39).

Recibió el primer debate el 26 de mayo de 1953, el segundo el día 28 y el tercer debate el día 29 de mayo.

La exposición de motivos la redactó la Comisión que, en lo referente al principio de inamovilidad (que es el aporte tal vez más importante del régimen del servicio civil) puntualizó: En cuanto a los derechos se consagra el principio de inamovilidad del servidor público, con el objeto de establecer la carrera administrativa como una profesión digna y decente, proscribiendo la funesta práctica del Ilamado sistema de "botín", cuyo nombre deriva de la célebre frase de un senador del estado de Nueva York cuando dijo: "A los vencedores corresponde el botín". Desde luego, se refería a los vencedores en la contienda electoral" (Asamblea expediente, p. 10).

Dicha frase corresponde al senador por Nueva York, William L. Marcy, quien en 1831 en un debate en el Congreso expresó "to the victor belong the spoils", frase que describe con exactitud el sistema de botín según el cual cada vez que una nueva administración entraba en el poder miles de servidores públicos eran despedidos y los miembros del partido político triunfante se hacía cargo de sus puestos de trabajo.

En Estados Unidos el spoil system, deja de existir con el Acta Pendleton de 1883 -en honor a su principal promotor el senador demócrata de Ohio George Pendleton-, lo que supone desde esa fecha, la utilización de un sistema neutral basado en criterios de igualdad y de mérito para acceder a un cargo público, algo que se logra en Costa Rica hasta con la promulgación del Estatuto.
El Estatuto está estructurado de la siguiente forma:

- El Título I que regula la Carrera Administrativa fue aprobado mediante la Ley n. ${ }^{0} 1581$ y cuenta con su propio Reglamento del Estatuto de Servicio Civil D.E. N. 21 del 16 de enero de 1955 y sus reformas.

- El Título II De la Carrera Docente le fue adicionado mediante la Ley n. 4565 del 4 de mayo de 1970 y cuenta con su Reglamento de la Ley de Carrera Docente, D.E. No. 2235- EP del 4 de febrero de 1972 y sus reformas.

- El Título III de El Tribunal de Servicio Civil adicionado mediante Ley n. 6155 del 28 de noviembre de 1977, que no ha sido reglamentado.

Finalmente, el Título IV Del Régimen Artístico le fue adicionado mediante Ley No. 8555 del 10 de octubre de 2006, el cual regula las relaciones de servicio entre el Poder Ejecutivo y los servidores públicos que brinden o desempeñen servicios o actividades artísticas (artes escénicas, audiovisuales, literarias, musicales, plásticas, así como sus combinaciones y que no pertenezcan a otro régimen) y cuenta con su propio reglamento que es el D.E. n. ${ }^{3}$ 34971-MP del 8 de diciembre de 2008.

\section{Jurisprudencia judicial más representativa}

La Sala Constitucional inició funciones en el año1989 y le ha correspondido analizar diferentes acciones de inconstitucionalidad establecidas en contra de artículos del Estatuto de Servicio Civil y resolver otra gran cantidad de recursos de amparo.

A continuación se analizan los votos más importantes emitidos por esa Sala. 
Los principios

constitucionales del régimen

Los artículos 191 y 192 constitucionales claramente mencionan los vocablos eficiencia de la Administración; idoneidad, causales de despido justificado.

Los alcances de la idoneidad (voto de la Sala Constitucional n. ${ }^{\circ}$ 12005- 01).

La idoneidad exigida es física, moral y psicológica y la Dirección del Servicio Civil está facultada para definir dichas pruebas.

Tiene efectivamente un claro sentido señalar que la idoneidad de los servidores públicos no solamente debe entenderse en un sentido específico, "académica" o "física" por ejemplo, sino que debe más bien asumirse como una conjunción de elementos o factores de diversa índole que, valorados en su conjunto producen que una persona resulte ser la más idónea para el cargo. Más aún, realmente no concibe la Sala la forma en que pudiera dejarse de considerar la necesaria "aptitud psicológica" no solo en términos generales de "estabilidad" o "normalidad", sino en lo que se refiere a las condiciones o "aptitudes específicas" que ciertos puestos requieran de modo necesario para ser ejercidos con eficiencia. Se trata entonces a juicio de la Sala de un medio adecuado y proporcionado de obtener el fin constitucional fijado en los artículos 191 y 192 Constitucionales, en tanto viene a complementar como se explicó los demás aspectos de la idoneidad; y esta misma razón la que hace que mantenga una primacía -en este caso concreto- frente a los otros derechos constitucionales que el recurrente considera involucrados en esta controversia, a saber, derecho a la igualdad de trato y derecho al trabajo, ello en el tanto que la aptitud psicológica, debe estimarse parte integrante de la idoneidad exigida por la propia Constitu- ción Política, según se explicó. Para concluir sobre este punto cabe señalar que, como en efecto lo señala el Director General del Servicio Civil, el Estatuto sí incorpora dentro de sus reglas la necesidad de la demostración - de forma amplia- de la idoneidad para el cargo y con ella la exigencia de comprobación de la idoneidad psicológica.

\section{Jurisprudencia sobre}

el Estatuto y reglamentos

- La constitucionalidad de la competencia del Tribunal de Servicio Civil (Voto 1148- 90). Reiterado en el voto 5227- 94.

La acción fue interpuesta en contra de la existencia misma en general, y las competencias en particular, del Tribunal de Servicio Civil, por considerar que implican la organización y funcionamiento de un tribunal de justicia fuera de la órbita exclusiva del Poder Judicial.

En la exposición de motivos del proyecto de ley del estatuto se indica sobre el Tribunal de Servicio Civil: "... se crea un Tribunal encargado de vigilar la pureza y corrección de los procedimientos sirviendo como cuerpo resolutivo en la querellas de los servidores que se sientan perjudicados en sus derechos"y la Sala Constitucional ratifica la condición jurídica del tribunal administrativo y en consecuencia declara:

a) Que la existencia y competencia del Tribunal de Servicio Civil no son contrarias per se a la Constitución, siempre que no se les otorgue carácter jurisdiccional sino únicamente administrativo, a efecto de tener por agotada esa vía como previa a la judicial contencioso-administrativa o, en su caso, laboral;

b) Que es inconstitucional la interpretación o aplicación de las disposiciones relativas al Tribunal de Servicio Civil, en la medida en que con aquella se atribuya a este o a sus 
competencias carácter jurisdiccional, o que se reconozca a sus fallos autoridad de cosa juzgada.

Además, en ejercicio de sus potestades para interpretar y aplicar los principios y normas constitucionales y, desde luego, los de la legislación común en la medida necesaria para acomodarlos a aquellos, la Sala declara:

a) Que la posibilidad del recurso de apelación previsto en el artículo 44 del Estatuto, contra algunas sentencias del Tribunal de Servicio Civil, ante el Superior de Trabajo, no convierte a este último en un órgano jurisdiccional en esta vía, sino que debe entendérsele siempre como órgano de instancia puramente administrativa - alzada- en ejercicio de una función administrativa tutelar;

b) Que, sin embargo, en virtud del principio general de derecho de que en sede administrativa debe haber una única instancia de alzada o reposición, debe interpretarse el artículo 44 de dicho Estatuto en el sentido de considerar suficiente la sentencia del Tribunal de Servicio Civil para que se tenga por agotada la vía administrativa, pudiendo, sin embargo, prescindirse de la instancia para ante el Tribunal Superior de Trabajo. No obstante, debe también entenderse que dicha instancia se mantendrá disponible, mientras no sea derogada por el legislador, pero solo como alternativa a opción del servidor público, de manera que, una vez producida la sentencia del primero, el interesado pueda hacer uso de ese recurso de alzada, o bien acudir, de una vez, a la jurisdicción común.

- La suspensión del funcionario como medida cautelar debe serlo con goce de salario (voto de la Sala Constitucional No. 927- 1994). En igual sentido el voto 2861-94; 5133- 94 y 2622-95.
El artículo 190 inciso ch) del Estatuto establece que es función del Tribunal de Servicio Civil “Decretar, en cualquier estado de las diligencias de gestión de despido, si lo considera pertinente con vista al mérito de los autos y a solicitud del respectivo Ministro actor, la suspensión provisional del servidor en el ejercicio del cargo".

Dichas suspensiones siempre lo fueron sin goce de salario lo que se prestó para abusos porque muchos funcionarios luego eran absueltos o ganaban el caso y no recibían salario inclusive por años, con lo cual tal suspensión se convertía en una sanción.

La Sala Constitucional cambia dicha interpretación en el año 1994 mediante una acción de inconstitucionalidad interpuesta en contra de la norma dicha y establece que dichas suspensiones, al ser medidas cautelares, deben serlo con goce de salario.

Por tal motivo, la suspensión no puede acordarse, en la forma en que tradicionalmente ha venido haciéndose, sin pago de salario al servidor, porque, entonces, perdería su carácter precautorio, para convertirse en una sanción anticipada, que viola el artículo 39 Constitucional, desde que este manda que no puede existir una sanción sin previa demostración de responsabilidad y sin la oportunidad concedida al afectado de ejercitar su defensa. Se trata, por decirlo de alguna manera, de un acto otorgado a favor de la Administración, dados los fines que cumple, pero no necesariamente contra o en perjuicio del servidor.

No obstante ya desde el año 1991, mediante recursos de amparo, se había establecido dicha doctrina.

... no se ha quebrantado el principio de non bis in ídem -consagrado en el artículo 42 de la Constitución Política-, ello por la circunstancia de que la única sanción que consta 
en contra de aquél, es la promoción de una gestión de despido por causas graves -a juicio de la institución recurrida- cuya procedencia o no debe dilucidarse, no en esta vía sino la legal correspondiente, ya que la suspensión sin goce de salario acordada con la finalidad de realizar la investigación pertinente, no se hizo efectiva en virtud de la gestión de revocatoria planteada por el recurrente -la cual, a juicio de esta Sala fue debidamente resuelta por cuanto no existe disposición alguna, que faculte al recurrido a acordarla con aquel propósito- (Voto No. 50-91 de las 16:29 horas del 4 de enero de 1991).

En el mes de setiembre de ese mismo año se emiten dos votos importantes. En el primero se señala que la suspensión con goce salario no es un enriquecimiento ilícito:

Como en el caso en examen, ninguna de esas circunstancias se encuentra demostrada, la administración bien puede suspender al funcionario para investigar si procede o no sancionarlo disciplinariamente con suspensión o revocatoria del nombramiento, pero la suspensión para el procedimiento lo será con goce de sueldo, lo contrario sería aceptar que el recibo de ese derecho vital esté a disposición de los intereses de la Administración, que por demás es quien puede acelerar o retardar la solución del asunto. En relación de ello en nuestro ordenamiento jurídico las suspensiones, para realizar investigaciones disciplinarias, no pueden ser sin goce de salario como lo señala la solicitante. El goce de salario no puede estimarse como un enriquecimiento ilícito, pues la relación laboral se mantiene durante la suspensión con todas sus consecuencias y prohibiciones (Voto No. 1791-91 de las 15:00 horas del 11 de setiembre de 1991).
En el segundo voto destaca que al funcionario lo protege la presunción constitucional de inocencia.

Está claro para la Sala, y así lo ha establecido en otras oportunidades, que el patrono puede, en aras del interés y del servicio público y mientras se concluye la investigación judicial, suspender al servidor. Pero, conjugando esa facultad con el principio consagrado por el artículo 39 que otorga al imputado un verdadero estado de inocencia, hasta tanto no se produzca sentencia firme que lo condene, la suspensión solamente puede realizarse con reconocimiento de los salarios, ya que de lo contrario se produciría una sanción anticipada y por ende, ilegítima (Sentencia N. ${ }^{\circ}$ 1837-91, 15:45 hrs., 18 de setiembre, 1991).

Posteriormente en el año 1993 en una acción de inconstitucionalidad interpuesta en contra del artículo 29 inciso 1) de la Ley Orgánica del Poder Judicial.

... la Sala considera que la facultad de la Corte para suspender cautelarmente a aquellos servidores judiciales contra los que se dicte auto de elevación a juicio, por hechos ilícitos cometidos en el ejercicio de sus funciones, resulta inconstitucional, -en tanto se acuerde sin el reconocimiento de salario para el trabajador afectado-; conclusión que, sin embargo, no se extrae necesariamente del texto cuestionado, el cual, por el contrario, permite una interpretación y aplicación conformes con la Constitución, siempre que se entienda que el ejercicio de esa potestad no puede afectar el derecho constitucional del servidor a su salario... (Sentencia 4014-93, de las 8:48 horas del 20 de agosto de 1993).

Esta misma interpretación jurisprudencial se aplica al artículo 90 del Reglamento del estatuto que establece: "Cuando así lo crea necesario, el Jefe podrá solicitar al Ministro, por medio de 
una fórmula de "Acción de Personal", la suspensión provisional del interesado en el ejercicio del cargo, a tenor del inciso d) del artículo 43 del Estatuto. El Ministro tendrá la responsabilidad de aprobar o improbar la suspensión y, en caso afirmativo, lo indicará a la Dirección General al someter por escrito su determinación de despido".

Dijo la Sala Constitucional:

En igual sentido, la suspensión a que se refiere el artículo 90 inciso b) del Reglamento al Estatuto del Servicio Civil, deberá decretarse a través de una resolución debidamente motivada y se entenderá que, en el tanto se trate de una suspensión provisional, lo será con goce de salario (Sentencia 2861 del 14 de junio de 1994).

- El término de prescripción para reclamar derechos derivados del Estatuto y sus reglamentos (voto 5969- 93, aclarado mediante el voto 280-94).

Mediante el primer voto la Sala Constitucional anuló por inconstitucionales el párrafo último del artículo 27 del Reglamento Autónomo de Servicio del Ministerio de Trabajo y Seguridad Social (Decreto número 19623-TSS publicado en "La Gaceta" número 93 del 17 de mayo de 1990), en cuanto establece la prescripción del derecho a vacaciones por remisión al artículo 607 del Código de Trabajo, el cual también anuló por inconstitucional, en cuanto se aplique a los derechos de los trabajadores únicamente, debiendo entenderse que para estos todos sus derechos laborales prescriben en los términos del artículo 602, a contar de la terminación del contrato de trabajo.

Adujo la Sala Constitucional que el instituto de la prescripción no es en su esencia inconstitucional, puesto que ayuda a integrar un principio básico del ordenamiento: la seguridad jurídica. No obstante, en el presente caso, estamos ante derechos que son, en conformidad con la nor- ma 74 de la Constitución, irrenunciables y, por ende, merecedores de una tutela especial incluso en cuanto a su régimen de prescripción, pues como ya se dijo, ha de tenerse en cuenta como único criterio aceptable de la prescripción, el principio de seguridad jurídica, pero sin admitir, se reitera, en relación con el artículo 74, que ese plazo sea válidamente de tan solo tres meses, en perjuicio del trabajador.

Este voto se aclaró mediante el No. 280- 94 haciéndolo extensivo al régimen del servicio civil y cualquier otro aplicable a los servidores públicos.

Se aclara la sentencia No 5969-93 de las 15:21 horas del 16 de noviembre de 1993, en el sentido de que la inconstitucionalidad allí declarada del artículo 607 del Código de Trabajo es aplicable a los servidores públicos amparados por el Servicio Civil u otros regímenes, a falta de disposiciones con rango de ley formal en contrario que regulen la prescripción en esas otras materias.

Igualmente mediante el voto No. 78-I-96 de las 14:30 horas de 20 de febrero de 1996 dispuso:

Se aclara la sentencia No 5969-93 de las 15:21 horas del 16 de noviembre de 1993, en el sentido de que el dimensionamiento que ella pronuncia, con el objeto de preservar el valor seguridad jurídica se refiere a las prescripciones operadas y formalmente declaradas; pero el dimensionamiento no se aplica a los derechos sobre los que no se ha hecho pronunciamiento jurisdiccional o administrativo expreso, antes o después del 14 de julio de 1992, en cuyo caso la prescripción acaecerá una vez transcurridos seis meses después de finalizada la relación laboral.

La regla general es que en materia de prescripción de derechos laborales y estatutarios tanto en el sector público como en el privado se aplica el artículo 607 del Código de Trabajo, de 
manera tal que todo derecho prescribe hasta un año después de haberse extinguido la relación laboral.

Ello es particularmente significativo en materia de anualidades cuyo derecho a reclamarlas no prescribe estando vigente la relación laboral.

Ha dicho la Sala Constitucional que de manera reiterada se ha pronunciado en cuanto a que el derecho a que se reconozcan anualidades no prescribe mientras se mantenga la relación laboral. Situación distinta se presenta una vez concluida la relación laboral. En ese sentido se ha pronunciado entre otras, en sus sentencias $N^{\circ}$. 227, de las 9:50 horas, del 31 de julio; 373 y 374, ambas del 20 de noviembre, todas de 1996; 378 , de las 14:50 horas del 14 de abril de 2000 y 26-04 de las 9:40 horas del 23 de enero de 2004.

De manera particular en este último voto dijo la Sala Constitucional que: "El derecho a que se reconozcan anualidades no prescribe mientras se mantenga la relación laboral...Situación distinta se presenta una vez concluida la relación laboral...porque en ese caso, entra en juego el instituto de la prescripción..."

Finalmente el inciso b) del 98 del Reglamento del Estatuto del Servicio Civil dispuso que prescribirán en dos meses:

b) Las acciones para pedir la ejecución de las resoluciones y fallos del Tribunal de Servicio Civil y del Tribunal Superior de Trabajo.

Dicha norma fue declarada inconstitucional mediante el voto 4367- 2003 al estimar la Sala que no puede crearse términos de prescripción vía reglamento ya que ello es reserva de ley.

- ¿Las incapacidades prolongadas son causal de despido? (Voto 4499- 94 y voto 15732008).

Este tema se refiere al artículo 36 del Reglamento del Estatuto, siendo la norma por muchos años más impugnada y la que mayor duda y polémica generó a lo interno de la Sala.

Estipula el mismo: "No obstante lo indicado en los artículos anteriores el servidor que permaneciere enfermo por un período de tres meses o más, podrá a juicio del máximo jerarca de la institución respectiva, ser separado de su puesto, mediante el pago del importe del preaviso y del auxilio de cesantía correspondientes."

La primera acción de inconstitucionalidad Corresponde al voto 4499-94. Se interpuso dicha acción de inconstitucionalidad aduciendo la recurrente que el Ministro de Salud ha decidido ponerle fin a su contrato laboral, en vista de la facultad que para ello le concede el artículo cuestionado. Estima que dicha disposición lo que establece en realidad es una causal de despido no autorizada por el Estatuto del Servicio Civil.

Empero, la Sala Constitucional la declara sin lugar aduciendo que no procede la inconstitucionalidad por omisión del artículo 43 del Estatuto sino que, simplemente, debe tenerse por entendido que, debido a la congruencia que guarda la norma reglamentaria con el artículo 192 de la Constitución, el supuesto del despido por enfermedad mayor de tres meses con el pago de los extremos correspondientes, es válido por estar también prevista en la legislación laboral y en consecuencia, debe entenderse contenido a su vez en la disposición del Estatuto del Servicio Civil.

En fin, estableció que no encontraba ningún roce de constitucionalidad entre tales normas y el derecho a la seguridad social y al trabajo criterio que fue ratificado en las sentencias No. 733694; No.1099-96 y No. 2364-99 de las 14:54 horas del 26 de marzo de 1999.

A partir de tales pronunciamientos, desestimó por igual numerosos recursos de amparo, en los que se aducía la infracción de derechos fundamentales por aplicación de un plazo máximo de 
incapacidad como causa de despido o de finalización del pago del subsidio correspondiente. Entre otros, están los votos No. 2000-8406 de las 10:02 horas del 22 de setiembre de 2000, No. 2001-2492 de las 16:24 horas del 27 de marzo de 2001, No.2002-232 de las 15:46 horas del 22 de enero de 2002, No.2004- 1798 de las 14:36 horas del 24 de febrero, No.2004-831 de las 15:00 horas del 18 de agosto, No.2004- 12354 de las 15:35 horas del 2 de noviembre, todas de 2004, No.2005-8742 de las 15:18 horas del 5 de julio de 2005 y No.2006-7096 de las 14:21 horas del 19 de mayo de 2006.

Sin embargo, en el año 2008 mediante el voto 1573- 2008, la Sala Constitucional cambia de criterio y lo declara inconstitucional por violentar el derecho a la seguridad social, a la solidaridad, al derecho a la salud y al trabajo.

En lo que interesa dijo:

Importa también recordar que la jurisprudencia constitucional ha vedado, aún en el campo de las relaciones laborales entre sujetos de derecho privado, que la enfermedad se convierta en un factor de discriminación en contra del empleado, que le haga derivar consecuencias perjudiciales a su situación (sentencias \# 2005-13205 de las 15:13 horas del 27 de septiembre del 2005 y \#2007-3168 de las 10:30 horas del 9 de marzo de 2007). En síntesis, el despido -aún mediando el pago de prestaciones completas- no es una solución que derive ni comulgue con los principios de justicia social ni de solidaridad. Debe existir una respuesta intermedia entre la incapacidad por enfermedad inferior a los tres meses y la incapacidad o invalidez permanente.

- Es constitucional la posibilidad de excluir ciertos puestos del régimen (los puestos de confianza) (Voto 5222- 94).
Un miembro de la fuerza pública catalogado como empleado de confianza impugnó el inciso b) del artículo 3 del estatuto que excluye de la protección del mismo a los miembros de la fuerza pública.

La Constitución misma señaló varios casos de funcionarios de libre escogencia y remoción como lo son los ministros de gobierno, los miembros de la fuerza pública, los directores de instituciones autónomas, representantes diplomáticos y, en general, "Ios empleados y funcionarios que ocupen cargos de confianza (artículo 140 inciso 1.), dejando a la Ley (Ley de Servicio Civil dice el artículo 140) la determinación de otros funcionarios, que en casos muy calificados, pudieran ser excluidos del régimen general. Esta posibilidad de excluir ciertos funcionarios la reitera el artículo 192.

Por otro lado, "empleados de confianza", son aquellos que han sido nombrados libremente por parte del funcionario que hace la escogencia, en conformidad con lo dispuesto en el artículo 140 inciso 1.) de la Constitución Política, que dice: "Son deberes y atribuciones que corresponden conjuntamente al Presidente y al respectivo Ministro de Gobierno: 1.) Nombrar y remover libremente a los miembros de la fuerza pública, a los empleados y funcionarios que sirvan cargos de confianza, y a los demás que determine en casos muy calificados, la Ley de Servicio Civil.."

Es decir, se trata de aquellos nombramientos en que no se siguen las reglas ni procedimientos ordinarios establecidos en el Estatuto de Servicio Civil, sino únicamente la discrecionalidad del jerarca que hace el nombramiento, en conformidad con lo dispuesto en los artículos 3 inciso c.) y 4 del Estatuto de Servicio Civil.

No obstante lo anterior, ha dicho la Sala Constitucional que los puestos de confianza no excluye el deber de velar por el cumplimiento de 
requisitos mínimos en los mismos, sea, el control de la idoneidad.

No obstante lo anterior, las condiciones de trabajo de los trabajadores de confianza serán proporcionadas a la naturaleza e importancia de los servicios que presten y no podrán ser inferiores a las que rijan para trabajos semejantes dentro de la institución, por lo cual, las condiciones de trabajo deben partir de los mínimos legales, en un ascenso que corresponda a la naturaleza e importancia del trabajo que prestan. En este orden de ideas esta Sala ha indicado que: “..., es lo cierto que los principios básicos del régimen (escogencia por idoneidad, estabilidad en el empleo) cubren a todos los funcionarios al servicio del Estado, tanto de la Administración Central, como de los entes descentralizados. Más esto en principio, porque el artículo 192 constitucional introduce otros elementos importantes al disponer al inicio "con las excepciones que esta Constitución y el estatuto de servicio civil determinen", frase que obliga a matizar las conclusiones anteriores, respecto al ámbito de aplicación del régimen o estatuto de servicio civil. Es obvio que en la mente del constituyente estaba la idea de que no todos los servidores públicos podían estar cubiertos por el régimen especial, pues la forma de escogencia, las capacidades, las funciones de cada cargo, las relaciones de confianza y dependencia no son iguales en todos los casos, de ahí que los principios derivados del artículo 192 son aplicables a ciertos funcionarios -la mayoría- no a todos (Voto 1119-90).

- La ejecución condicional de la pena ¿impedimento para hacer oferta de servicios? (Voto 5597- 1996).

Los artículos 20 inciso a) del Estatuto de Servicio Civil, 9 inciso c) y 15 de su Reglamento, venían siendo interpretados por la Dirección General de Servicio Civil en el sentido de que no es procedente tramitar ofertas de servicio ni nombramientos a quienes se encuentren en el período del beneficio de ejecución condicional de la pena.

La Sala Constitucional acoge la acción y, en consecuencia, declara inconstitucional la interpretación dicha y anula las resoluciones de esa Dirección número DG-058-92 de las 11:00 horas del 7 de mayo de 1992 y DG-082-94 de las 14:00 horas del 5 de setiembre de 1994.

El principal argumento, a juicio de la Sala, sobre la inconstitucionalidad de la norma impugnada se encuentra en la alegada contradicción de esta con lo establecido en el artículo 40 de la Constitución Política, el cual expresamente determina la prohibición de penas perpetuas en nuestro ordenamiento jurídico: "Nadie será sometido a tratamientos crueles o degradantes ni a penas perpetuas (...)". Las penas contempladas por nuestro derecho, establecidas en el artículo 50 del Código Penal, son: prisión, extrañamiento, multa e inhabilitación, como penas principales, y la inhabilitación especial, como pena accesoria.

Es claro, por lo tanto, que cualquier tipo de pena a que se vea sometida una persona debe respetar el mandato constitucional del citado artículo 40. Además, la naturaleza jurídica de las sanciones penales implica que estas solo son empleadas cuando el tipo penal contempla expresamente dicha pena como aplicable al correspondiente delito, (conforme el principio de tipicidad penal), siendo determinada en sentencia por el juez penal, una vez realizado el proceso respectivo -en el que el imputado es intimado de los hechos que basan la acusación y de las sanciones previstas por la ley para dichos actos-, y sea comprobada su responsabilidad penal. Así, no se podría imponer una pena de inhabilitación o inhabilitación especial si el tipo penal no la contempla para el hecho delictivo concreto, y en el caso en que sí proceda la inhabilitación como pena, esta 
nunca podría ser perpetua, conforme lo establece la Constitución Política.

- La potestad de la Administración para disponer la reubicación física de funcionarios. (Artículos 22 bis y 50 del Reglamento del Estatuto de Servicio Civil) (Voto 2231- 1992).

II- Respecto del cambio físico de puesto, ya esta Sala en otros casos similares ha dicho que es constitucionalmente legítima la potestad de la administración de cambiar a sus servidores de lugar de trabajo, siempre y cuando exista como causa de ello el interés público; debiendo observarse también, el equilibrio que dispone, entre otros, el ordinal 8 de la Ley General de la Administración Pública y las facultades y restricciones que como patrono le confieren el ius variandi en nuestro ordenamiento ...En este sentido, se requiere que demuestre esa necesidad señalando, como en oportunidades anteriores lo ha hecho el Estado, las causas legítimas, verdaderas, técnicas y racionales, que motivan y hacen necesario que el servidor trabaje en otro lugar...

Dicho criterio fue reiterado en el voto 309- 2000 indicando que: "Además de lo anterior y como reiteradamente lo ha dicho la Sala en numerosa jurisprudencia, la Administración puede ejercer el ius variandi, siempre y cuando se respeten los derechos del funcionario en el sentido de que se tome en cuenta que cualquier decisión no debe ir en detrimento de aquellos derechos adquiridos por el funcionario".

Igualmente de manera contundente en el voto 668- 2000 estipuló:

Es claro entonces que la reubicación ha sido efectuada en ejercicio de las facultades otorgadas a la Administración por los artículos 22 bis y 50 del Reglamento del Estatuto de Servicio Civil y que no le causa a la amparada ninguna variación en relación con el puesto, funciones, horario ni salario, además de que la Administración le suministrará el transporte diario y las comidas en el Centro Penal. El interés público prevalece frente a los inconvenientes personales que el traslado le cause a la amparada. En consecuencia, este Tribunal considera que no se ha producido quebranto alguno a sus derechos fundamentales, por lo que procede desestimar el recurso.

- El derecho de los extranjeros de acceder al régimen en igualdad de condiciones (Voto 5569- 2000).

El Estatuto estableció por décadas que para poder ingresar al régimen era requisito ser costarricense.

Adujo la Sala que en cuanto a la utilización de la nacionalidad como criterio para limitar a los extranjeros la facultad de acceder a determinado empleo, debe tenerse en cuenta, como se dijo en el considerando anterior, que esa disposición, lejos de justificarse en sí misma, necesita una base fáctica que le sirva de fundamento y que permita considerar razonable la creación de esta disposición; caso contrario, dicha situación constituye una evidente lesión del derecho de igualdad, así como del contenido del artículo 19 de la Constitución Política.

Así, los extranjeros -previo cumplimiento de los requisitos legales que le permiten laborar en nuestro país- tienen la misma posibilidad que un costarricense de acceder a determinado empleo, según lo dispuesto por los artículos 19 y 33 de la Constitución Política. En síntesis, la Constitución adopta el criterio de igualdad de derechos entre nacionales y extranjeros, por lo que una disposición atinente a limitar la posibilidad de acceder a determinada ocupación, solamente por su nacionalidad, designa una evidente contradicción al contenido de las normas constitucionales supra mencionadas. 
Concluyó la Sala Constitucional expresando que la igualdad de trato a nacionales y extranjeros en materia de trabajo está consagrada no solo en los instrumentos de Derechos Humanos vigentes o aplicables en Costa Rica, sino que incluso lo está de manera expresa por el Convenio de la Organización Internacional del Trabajo n. ${ }^{0} 111$ sobre discriminación en el empleo, por lo que anuló, por inconstitucionales, el inciso a) del artículo 9 del Reglamento del Estatuto del Servicio Civil; el inciso b del artículo 5 del Reglamento de la Carrera Docente y, por conexidad, el aparte 2 del inciso a) del artículo 55 del Estatuto del Servicio Civil (ser costarricense).

- La indemnización debe serlo en un solo pago y no en tractos. El artículo 37 inciso f) (Voto 8232- 2000).

Este inciso estipula que si los servidores públicos amparados al Estatuto cesaren en sus funciones por supresión del empleo, tendrán derecho a una indemnización de un mes por cada año o fracción de seis meses de servicios prestados. Agrega, sin embargo que: "Tal indemnización se satisfará por mensualidades consecutivas, del monto del sueldo devengado, a partir de la supresión del empleo y hasta completar el límite del derecho respectivo", contenida en el artículo 37 inciso f) del Estatuto de Servicio Civil".

La Sala declaró inconstitucional dicha frase al considerar que, la naturaleza de la suma de dinero que se ordena pagar al servidor de acuerdo con las de esta norma es de carácter resarcitorio por el daño que el Estado le causa al servidor por privarle de su medio de subsistencia.

Al descartar que la indemnización, de dicha norma no es un seguro de desocupación, analizó la constitucionalidad de que se pague la indemnización en forma diferida: la carga económica que constituye para el Estado pagarla, dado que, por tomar en cuenta todos los años de servicio del trabajador para el cálculo de la indemniza- ción, el Estado debe desembolsar grandes sumas de dinero, lo que resulta una carga pesada para el erario público.

A juicio de este Tribunal, atenuar la carga económica para la administración no es un motivo constitucionalmente legítimo para justificar que se pague a estos servidores la indemnización en forma diferida. El monto que le corresponde al servidor de acuerdo con el Estatuto de Servicio Civil es un derecho suyo, parte de su patrimonio, cobijado constitucionalmente por el artículo 63 de la Constitución Política. Obedece a que es privado de su empleo por razones excepcionales que la ley autoriza, pese a que pertenece a un régimen que asegura la estabilidad en el empleo. Por ello, el Estado debe indemnizar la supresión del cargo a partir del momento en que el servidor debe dejarlo, por lo que a juicio de la Sala el hecho de que se le prive de su fuente de trabajo sin el pago completo de la indemnización, constituye una afectación a su patrimonio que lesiona el numeral 45 de la Constitución Política. Es intrascendente el destino que el servidor de a esos recursos, pues como parte de su peculio, puede disponer de ellos como a bien lo tenga.

- Pruebas de aptitud psicológicas o psíquicas no son inconstitucionales (Voto 120052001).

La acción se interpuso por la supuesta extralimitación de la facultad reglamentaria del Poder Ejecutivo, al incluir -como requisito formal de ingreso y como componente de la idoneidaden los artículos 9 inciso c) y 15 primero párrafo, la necesidad de poseer una "aptitud psíquica" lo cual no tiene ningún asidero legal en el Estatuto puesto que este último se limita a señalar las aptitudes "moral y física", excluyendo todas las demás, según la tesis del recurrente.

No obstante la Sala Constitucional concluye indicando que: 
...no se ha cometido infracción alguna con la inclusión por parte del Reglamento del Servicio Civil, de pruebas destinadas a comprobar la "aptitud psicológica o psíquica" como parte de la condición de idoneidad establecida tanto en la Constitución Política como en el Estatuto del Servicio Civil. De igual forma, tampoco la inclusión de este tipo de pruebas en el reglamento infringe el orden y valor de los requisitos regulado por el Estatuto, dado que, como se indicó, las señaladas pruebas se aplican no como paso previo sino como parte integrante del proceso de demostración de idoneidad que justamente exige el Estatuto. Finalmente, no existe omisión alguna en cuanto las posibilidades de impugnación, dado que existe no solo un procedimiento, para la puesta en conocimiento de los resultados de las pruebas, sino que el tema está cubierto igualmente por el régimen general de impugnación que establecen tanto el Estatuto como su Reglamento.

- Prisión preventiva que exceda tres meses es justa causa de despido. (Voto 2661- 2001).

Se impugnó dicha norma que dice: "Para garantizar mejor el buen servicio público se establecen cuatro clases de sanciones disciplinarias: d) La suspensión del trabajo sin goce de sueldo procederá también en los casos de arresto y prisión preventiva, durante todo el tiempo que uno y otra se mantengan, pero dará lugar al despido en cuanto excedan de tres meses".

La Sala Constitucional declaró que dicha norma no lesiona el principio de presunción de inocencia siempre y cuando se paguen las prestaciones legales.

Al respecto esta Sala descarta la violación al principio de inocencia en el entendido de que medie el pago de prestaciones laborales al funcionario y reitera que en el proceso penal costarricense el imputado es considerado inocente en todas las etapas del procedimiento hasta que una sentencia firme establezca su culpabilidad; situación que es independiente de la causa legal de remoción en contra del trabajador, pues lo que se verifica es si el plazo que el trabajador ha permanecido separado de su puesto por prisión excede los tres meses y no la definición de su situación jurídica" (destacado no es del original).

- Resoluciones del Tribunal de Carrera Docente tienen apelación ante el Ministro quien agota la vía (Voto 5419- 2001).

El artículo 81,b) del Estatuto del Servicio Civil reza:

El Tribunal de la Carrera Docente tendrá las siguientes atribuciones:

b) Conocer de lo resuelto por el Director del Departamento de Personal, en relación con las peticiones de los servidores, sobre derechos inherentes a ellos en sus puestos. La resolución, en estos casos, tendrá alzada ante el Ministro de Educación Pública. Tal trámite agota la vía respectiva.

Por su parte, el artículo 25,b) del Reglamento de Carrera Docente se lee:

El Tribunal de la Carrera Docente tendrá las siguientes atribuciones:

b) Conocer, en apelación, de lo resuelto por el Director del Departamento de Personal, en relación con las peticiones de mejoramiento individuales que los servidores docentes formulen, referentes a derechos inherentes a ellos, en sus puestos. La resolución, en estos casos, tendrá alzada ante el Ministro.

Cumplido este trámite se tendrá por agotada la vía administrativa y en caso de plantearse reclamo ante el Tribunal de Servicio Civil se seguirá 
el procedimiento que se indica en el inciso anterior...

La Sala Constitucional declaró que es constitucional dicha normativa y que es procedente que las resoluciones de dicho tribunal tengan alzada ante el Ministro de Educación aduciendo lo siguiente.

El artículo 41 de la Constitución Política establece que recurriendo a las leyes, todos han de encontrar reparación para las injurias o daños que hayan recibido en su persona, propiedad o intereses morales y que debe hacérseles justicia pronta, cumplida, sin denegación y en estricta conformidad con las leyes. Este artículo establece una serie de principios básicos a los cuales los individuos y el Estado deben ajustar su actuación en el ámbito de la justicia. Por una parte, implica que las leyes deben orientarse a procurar la tutela de los derechos quebrantados mediante normas que regulen el derecho de cada persona y que, por otra, establezcan los instrumentos procesales adecuados para que las personas tengan acceso a la justicia y los órganos competentes, tanto en sede judicial como administrativa, la otorguen en caso de considerar vulnerados los derechos de las personas.

Desde un punto de vista sustancial implica la tutela efectiva de los derechos de las personas $y$, desde una perspectiva formal, hace referencia a la creación de mecanismos efectivos a disposición de las personas para la defensa de sus derechos en caso de considerarlos lesionados. En este caso, desde la perspectiva del principio de justicia efectiva o cumplida, la norma aquí cuestionada no resulta inconstitucional en el tanto supone un mecanismo otorgado a favor de quienes pudieran verse afectados en sus derechos para que accedan a una instancia superior que analice las circunstancias de hechos y las razones de derecho que tuvo la Administración en su actuar y que eventualmente implicarían una vulneración de los derechos de las personas.
Desde una perspectiva procedimental, es la conformación de un mecanismo por medio del cual el administrado puede impugnar los actos administrativos que considera lesivos de sus derechos o intereses, cumpliendo así con los requerimientos constitucionalmente consagrados.

Contrariamente a lo indicado por el accionante, no puede considerarse que la creación de una instancia de reclamo ante el superior jerárquico implique quebrantamiento al principio de justicia pronta y cumplida por la tardanza que esto pudiera implicar en la resolución definitiva del asunto en sede administrativa, el agotamiento de esta vía y las posibilidades de acceso a la sede jurisdiccional. La transgresión de dicho principio se configuraría en el momento en que el órgano encargado de resolver incurriera en un retraso injustificado, lo que eventualmente podría ser objeto del un recurso de amparo pero no de una acción de inconstitucionalidad.

- El término de artículo 26 del Reglamento de la Carrera Docente no es de caducidad (Voto 1764- 2002).

Este artículo menciona, en lo concerniente, que cuando existiere queja o denuncia por la presunta comisión de falta grave o de alguna gravedad, contra un servidor docente, según se detalla en los artículos 65 y 66 del Estatuto de Servicio Civil, la Dirección General de Personal mediante el Departamento de Procedimientos Legales, realizará una investigación de los hechos denunciados, que deberá concluirse en un lapso no mayor de tres meses.

La Sala Constitucional declaró:

Que es inconstitucional y por ello se anula del ordenamiento jurídico, la interpretación que se ha constituido en jurisprudencia administrativa y como tal de obligatoria aplicación, dictada por el Tribunal de Carrera Docente y que ha prohijado la Dirección de Personal del Ministerio de Educación Públi- 
ca, en el sentido de que los plazos procesales derivados de los artículos 26 del Reglamento de la Carrera Docente (...) dan contenido a un verdadero término de caducidad...

Es criterio de la Sala que es jurídicamente imposible derivar una prescripción o una caducidad, de una norma reglamentaria o de rango inferior, que no tenga sustento en una norma legal. Así lo expresó la Sala en la sentencia número 378396. En consecuencia, para ella resulta evidente que la interpretación que hacen las autoridades docentes, y que se traduce en su propia jurisprudencia reiterada y de obligada aplicación a lo interno de los procesos sancionatorios administrativos, resulta inconstitucional por no conformarse con los principios básicos que dirigen y regulan las limitaciones de los derechos fundamentales.

En suma, para ese tribunal es más que evidente, que se trata de un término ordenatorio y no perentorio como lo venía interpretando el Ministerio de Educación.

- Es procedente declarar la no idoneidad temporal de un exfuncionario por haber sido despedido de su puesto sin responsabilidad patronal (Voto 6057- 2002).

El accionante solicitó que la Sala declare la inconstitucionalidad del numeral 9 inciso f) del Reglamento al Estatuto de Servicio Civil, por infringir los artículos 33, 39 y 56 de la Constitución Política. La norma dispone lo siguiente:

Son requisitos para ingresar al Servicio Civil, aparte de lo establecido por el artículo 20 del Estatuto, los siguientes:

f) No haber sido destituido por infracción de las disposiciones del Estatuto, del presente Reglamento o de los reglamentos autónomos respectivos en los tres años anteriores a la fecha de ingreso, o en un plazo mayor, si a juicio de la Dirección General, la gravedad de la falta lo amerita.

Declara sin lugar la acción aduciendo que:

Tómese en cuenta que no se trata de una sanción adicional al despido, como parece entenderlo el accionante, sino a la regulación de las consecuencias jurídicas de un hecho, con la que el Estado se protege de conductas irregulares que minan la subordinación que todo servidor debe al Estado como patrono, y al ordenamiento, de manera que al constatarse una falta por la que se debió aplicar el poder sancionatorio, como medio para exigir el cumplimiento exacto de los deberes de la función pública o el rompimiento de la relación de servicio según las causales existentes, ello deberá formar parte de los requisitos de reingreso al servicio civil.

El principio general consiste, entonces, en que al haber infringido la normativa del Estatuto de Servicio Civil, quedan condicionados los futuros nombramientos en el Poder Ejecutivo bajo ese régimen, a que no hayan sido destituidos anteriormente de sus puestos por la infracción de disposiciones del Estatuto, del Reglamento al Estatuto o de reglamentos autónomos por un plazo de tres años, o uno mayor, según la gravedad de la falta.

- Los títulos universitarios no deben ser solo de la Universidad de Costa Rica (Voto 2423- 07).

En esta acción se impugnó el inciso b) del artículo 122 del Estatuto que dice:

Artículo 122.-

Los profesores titulares de enseñanza primaria se clasifican en seis grupos, denominados PT-6, PT-5. PT-4, PT-3, PT-2 y PT-1(...)

b) Forman el grupo PT-5 los Bachilleres en Ciencias de la Educación, con especialidad 
en Primaria; además los profesores de enseñanza primaria que hayan aprobado los estudios de especialidad en Primaria, exigidos al Bachiller en Ciencias de la Educación y posean el Certificado de Idoneidad, extendido por la Universidad de Costa Rica(...).

La Sala Constitucional anuló la frase "extendido por la Universidad de Costa Rica" aduciendo que no se justifica que los egresados de la Universidad de Costa Rica tengan exclusividad para la obtención de ascensos en el Servicio Civil, pues es claro que si cualquier otra universidad tiene los requisitos para operar conforme a las reglas y normativa vigente, el Estado debe darle igual reconocimiento. Así las cosas, aun cuando la intención del legislador al crear la norma no era hacer una diferencia odiosa, pues la carrera en cuestión únicamente se impartía en la Universidad de Costa Rica, lo cierto es que en la actualidad no se justifica mantener dicha diferenciación.

Sobre un tema muy similar al aquí planteado la Sala ya se había referido mediante sentencia número 110-98 de las diez horas veintisiete minutos del nueve de enero de mil novecientos noventa y ocho, en la cual indicó en lo conducente:

Lo que sí resulta inconstitucional, es: a) exigir que si el título es nacional lo sea de la Universidad de Costa Rica, y, b) solicitar que si el título fue obtenido en el extranjero se deba presentar una certificación de dicha Institución (UCR) en que conste que a los solicitantes se les ha convalidado los estudios hechos. La primera inconstitucionalidad es evidente porque en la actualidad el Estado ha reconocido el funcionamiento de otras universidades estatales y privadas, las cuales conforme al derecho de igualdad y de educación, no podrían tener un tratamiento diverso con respecto a la Universidad de Costa Rica, siempre que se trate de Universidades y carreras legalmente autorizadas. Precisamente este tema fue objeto de una reforma constitucional en mil novecientos setenta y cinco, que agregó al artículo 86 de la Constitución la frase "de las demás instituciones de educación superior universitaria", para referirse también a las privadas, ya que la norma originalmente solo lo hacía en relación con la Universidad de Costa Rica. También, en cuanto a las demás instituciones de educación superior estatal, el artículo 84 de la Carta Política les otorga "la misma independencia funcional e igual capacidad jurídica que la Universidad de Costa Rica", de tal forma que tampoco en cuanto a estas es constitucional la diferenciación que hace la norma, la cual debe interpretarse y entenderse en el sentido señalado.

- $\quad$ El tope de treinta anualidades del artículo 5 de la Ley de Salarios de las Administración Pública (Voto 15460- 2008). Reiterado en el voto 18206- 08.

El artículo $5^{\circ}$ de la Ley de Salarios de la Administración Pública, Ley No. 2166 del 9 de octubre de 1957, estableció por décadas lo siguiente:

De conformidad con esta escala de sueldos, cada categoría tendrá aumentos o pasos, hasta un total de treinta, de acuerdo con los montos señalados en el artículo $4^{\circ}$ anterior, hasta llegar al sueldo máximo, que será la suma del salario base más los treinta pasos o aumentos anuales de la correspondiente categoría. Todo servidor comenzará devengando el mínimo de la categoría que le corresponde al puesto, salvo en casos de inopia a juicio del Ministro respectivo y de la Dirección General de Servicio Civil. Los aumentos anuales serán concedidos por méritos a aquellos servidores que hayan recibido calificación por lo menos de "bueno", en el año anterior, otorgándoseles un paso adicional, dentro de la misma categoría, hasta llegar al sueldo máximo. (Así reformado por Ley No 6408 de 14 de marzo de 1980, artículo 10). 
La Sala, en el voto que nos ocupa, resolvió anular por inconstitucionales, la frase "hasta un total de treinta" y la palabra "treinta" del artículo $5^{\circ}$ de la Ley de Salarios de la Administración Pública No. 2166 de 9 de octubre de 1957. Dicha declaratoria de inconstitucionalidad, para evitar graves dislocaciones de la seguridad jurídica, no tiene efectos retroactivos por lo que se deben respetar las situaciones jurídicas consolidadas.

Por otro lado, se dimensionó en el tiempo los efectos de la declaración de inconstitucionalidad en el siguiente sentido: a) La declaratoria de inconstitucionalidad rige a partir de la publicación de las sentencia por lo que podrá ser aplicada a los funcionarios o servidores públicos que, para ese momento, no han cumplido las treinta anualidades; b) en el caso de los servidores públicos que se encuentren en servicio activo y superen las treinta anualidades no podrán pretender las diferencias salariales y sus accesorios con efecto retroactivo, debe el patrono acordar el reajuste de salario a partir de la publicación de la sentencia; c) las personas a quienes se les haya otorgado una pensión o jubilación no podrán pretender su reajuste y sus accesorios con fundamento en la eliminación del tope de las treinta anualidades, incluso, si hubieren laborado más de treinta años; d) quienes estuvieren en la condición anterior y hayan reingresado al servicio activo tampoco podrán pretender el reajuste de la pensión o jubilación o las diferencias salariales, únicamente, el reajuste del salario en el nuevo puesto a partir de la publicación de la sentencia.

Dicho fallo fue sustentado en el hecho de que la norma en comentario infringía los principios constitucionales de intangibilidad relativa del patrimonio, razonabilidad y el derecho a la protección especial del adulto mayor.

- El arbitraje obligatorio no es aplicable en el sector público (Voto 1696-92).

El artículo 368, frase segunda y 521, párrafo segundo del Código de Trabajo, sometían obliga- toriamente a la Administración Pública a dirimir, en la vía del procedimiento de arbitraje obligatorio, los conflictos colectivos que se suscitan con sus servidores públicos, lo cual fue declarado inconstitucional porque debe prevalecer el régimen estatutario sobre el laboral.

Adujo la Sala Constitucional en este voto que la intervención de los Tribunales de Trabajo, con el procedimiento de arbitraje obligatorio para los servicios públicos, en los términos de los artículos del Código de Trabajo impugnados, tuvo origen en otro orden constitucional pues dicho cuerpo de normas data de 1943 y bajo otras necesidades, sin que existiera -en ese momento- la concepción constitucional de un régimen laboral público, exclusivo para los servidores del Estado, a fin de regular y dirimir las diversas situaciones que afectan esa relación.

Rige actualmente -empero- una Constitución Política que sí lo previó y que, no obstante ello, se sigue utilizando un orden legal común, sometiéndose a la Administración Pública y sus empleados, a la resolución de sus diferencias mediante un procedimiento de índole privado. Esto resulta en una aplicación inconstitucional en virtud del desfase histórico y jurídico que esta materia evidencia, lo que contraviene tácitamente el artículo 197 de la Constitución Política. Es claro que la intención del constituyente era la de crear un régimen laboral administrativo. De la lectura de las actas de la Asamblea Nacional Constituyente se distingue la figura del empleado público y del trabajador privado. Es indudable que la ausencia de un régimen jurídico que regule apropiadamente las relaciones entre el Estado y sus servidores, quebranta el artículo 191 de la Constitución Política, lo que conlleva también al quebrantamiento del artículo 11 de la Carta Magna pues, ...toda norma u acto inconstitucional lo viola, por definición, en tanto que consagra el principio de legalidad según el cual los funcionarios públicos no pueden ejercer otras funciones que las que les están otorgadas 
por el ordenamiento y este no las otorga en ningún caso para realizar los que sean contrarios a la Constitución" (Sala Constitucional, Resolución N 550-91, de las dieciocho horas cincuenta minutos del quince de marzo de mil novecientos noventa y uno).

- La doctrina jurisprudencia del Estado como patrono único (Voto Sala Segunda 90-89). Reiterado en los votos 92- 89; 169- 89 y 90-90.

Así como la Sala Constitucional ha hecho aportes importantes en la consolidación del régimen de servicio civil, la jurisprudencia laboral ha hecho lo propio, fundamentalmente con la elaboración de la doctrina del Estado como patrono único, consistente en que, independientemente en que institución pública ha laborado el funcionario, ya sea del gobierno central o descentralizado, o en el gobierno municipal, y sin importar el estatuto específico por el que se rigió su relación laboral, dicha relación es una sola en todo el Estado costarricense para efectos de continuidad en el cálculo de vacaciones; pensión, y auxilio de cesantía y posteriormente para efectos del cómputo de anualidades.

Dicha doctrina se empezó a gestar en las sentencias No 1388 del 3 de noviembre de 1958, № 105 del 12 de enero de 1973, del Tribunal Superior de Trabajo de San José, y No 95 de la antigua Sala de Casación y en los dictámenes de la Procuraduría General de la República C 194-88 del 17 de junio de 1983, C 236-85 del 30 de setiembre de 1985, C 081-85 (4) del 16 de abril del mismo año.

\section{El período de prueba en la jurisprudencia}

El artículo 30 del Estatuto establece que para que un servidor público reciba la protección de esta ley, deberá pasar satisfactoriamente un período de prueba hasta de tres meses de servicio contados a partir de la fecha de vigencia del acuerdo de nombramiento.
Existe una copiosa e importante jurisprudencia sobre el particular.

Perío do de prueba debe interpretarse a favor del funcionario (Voto 2727- 2004)

Los artículos 101 en relación con el 30 del Estatuto del Servicio Civil deben interpretarse a favor del servidor, en el sentido de que, en los casos en que mediante concurso se ha obtenido una plaza en propiedad, de la cual se prescinde por disminución de matrícula u otra causa no imputable al interesado, el hecho de que este no haya cumplido el periodo de prueba previsto en el segundo no impide que se le traslade en propiedad, para que cumpla, en la nueva plaza, el periodo de prueba.

\section{Puede exigirse en traslados}

y ascensos (Voto 5658-2004)

Este Tribunal Constitucional ha reconocido que para que un servidor público reciba la protección que la ley contempla para cada caso concreto, debe pasar, satisfactoriamente, un período de prueba -el que generalmente es de tres meses de servicio- contado a partir de la fecha de vigencia del acuerdo de su nombramiento. También ha reconocido, por regla general, que el período de prueba se aplicará en los casos de iniciación de contrato, pero, a juicio del jerarca respectivo, podrá exigirse en todos los casos de promoción o traslado en que convenga, para garantizar el buen funcionamiento del servicio público y que el Jefe autorizado podrá despedir, libremente, al empleado durante ese período.

Despido el período de prueba es libre y discrecional:

- " "...de la aprueba documental allegada a los autos, este Tribunal Constitucional considera que el cese del nombramiento de la actora no viola sus derechos fundamentales, en 
la medida en que se tiene por demostrado que esa actuación responde, exclusivamente, al resultado de la calificación que obtuvo la recurrente durante el término en que estuvo sometida al período de prueba en la Corporación recurrida." (Sala Constitucional voto No. 5103-2002).

- "...Sobre el despido durante el período de prueba. Este Tribunal Constitucional ha conocido sobre el tema del despido durante el período de prueba establecido por el Estatuto del Servicio Civil y se ha forjado un criterio uniforme a partir del cual la Administración puede remover libremente a los funcionarios que no demuestren idoneidad durante dicho período de prueba.

Así por ejemplo, en sentencia número 628794, de las quince horas cincuenta y siete minutos del veintiséis de octubre de mil novecientos noventa y cuatro, esta Sala estableció en lo conducente que: "...IV.- No lleva razón el recurrente al afirmar que resulte contrario al debido proceso, el hecho de que el patrono despida al trabajador en el período de prueba, toda vez que la finalidad de este instituto es garantizar al primero la eficacia del servidor en el desempeño de las funciones encomendadas, por esa razón no resulta arbitraria la destitución que se acordara en ese lapso, siempre y cuando se fundamenten las causas que justifican la decisión adoptada..." (Voto 4529- 2004).

- "En reiteradas oportunidades este Tribunal ha señalado que la decisión de despedir a un servidor dentro del período de prueba es libre y de carácter discrecional. Para su adopción no es necesario observar las reglas propias del debido proceso. En este sentido, pueden citarse como antecedentes recientes las sentencias número 2002-01455 de las 15:32 horas del 12 de febrero, 200203016 de las 11:10 horas del $1^{\circ}$ de marzo,
2002-07388 de las 8:51 horas del 26 de julio, 2002-09420 de las 16:07 horas del 26 de setiembre y 2002-11911 de las 13:31 horas del 13 de diciembre, todas las fechas de 2002 y 2003-3244 de las 11:37 horas del 25 de abril de 2003" (Sala Constitucional voto No. 51272003. En el mismo sentido 2307-2005.

- $\quad$ "Así, se ha reconocido que durante el periodo de prueba el empleador cuenta con una gran discrecionalidad para decidir sobre la permanencia del funcionario en el puesto, ya que, precisamente, con ese fin es que se prevé ese periodo, en la medida que tiene la finalidad de garantizar la eficacia del servidor en el desempeño de las funciones encomendadas. Por ello, el funcionario puede ser removido por el Jefe autorizado, siempre y cuando las razones que se aleguen para el despido no sean antojadizas, discriminatorias o vayan a configurar un abuso de poder" (Voto 70812009). En el mismo sentido voto 6431- 2009).

- "Cabe reiterar que esta Sala ha resuelto, de forma reiterada, que la decisión de despedir o prescindir de un servidor dentro del período de prueba es de carácter discrecional, y se puede disponer de estimarse que el servidor no es idóneo para desempeñar el puesto, sin que para la adopción de tal determinación sea necesario observar las reglas propias del debido proceso. Y es que la finalidad del período de prueba es justamente garantizar al patrono la eficacia e idoneidad del servidor en el desempeño de las funciones encomendadas" (Voto 2235- 09).

\section{El servidor interino}

\section{está sujeto a período de prueba}

- "En la especie se tiene plenamente acreditado -conforme a la anterior relación de hechos probados-, que a la recurrente se le comunicó el cese de su nombramiento interino cuando aún no había superado el pe- 
ríodo de prueba, y por haberse demostrado su falta de idoneidad para el ejercicio de las funciones propias del cargo, por lo que no puede estimarse que lo actuado por la autoridad recurrida sea arbitrario, o en general, violatorio del derecho a la estabilidad laboral (ver, en similar sentido, sentencias número 3411-97 de las 17:51 horas del 18 de junio de 1997 y 2001-10653 de las 10:12 horas del 19 de octubre del 2001)"Voto 2235-09.

- "(...) En reiteradas ocasiones, esta Sala ha afirmado que un servidor interino solo puede ser sustituido por uno nombrado en propiedad, no por otro interino. Si bien el funcionario interino no goza de inamovilidad en el puesto, sí posee estabilidad, que puede hacerla valer frente a cualquier otro empleado público que pretenda un nombramiento interino en la plaza por él ocupada. En el caso del nombramiento en sustitución del propietario, la designación está subordinada a la eventualidad del regreso al puesto del funcionario titular, en cuyo caso debe cesar la designación del interino, ya que ese tipo de nombramiento no le es oponible al propietario. En caso de plazas vacantes, el servidor interino goza de una estabilidad relativa o impropia, en el sentido de que no puede ser cesado de su puesto a menos que se nombre en él a otro funcionario en propiedad. Tal estabilidad, sin embargo, está supeditada a que el funcionario interino supere el periodo de prueba. Una actuación de la Administración contraria a lo expuesto constituye una violación al derecho a la estabilidad laboral del servidor interino, cobijado en el artículo 56 de la Constitución Política"(el subrayado no corresponde al original) Voto 10695- 2006. Reiterado en el voto 2235- 2009.

\section{CONCLUSIONES}

El Régimen del Servicio Civil se crea en Costa Rica a partir de la Constitución de 1949, lo que provoca que las relaciones entre el Estado y sus servidores ya no sean reguladas por el Código de Trabajo, puesto que pasan a ser regentadas por un nuevo régimen propio del Derecho Público que se denomina usualmente como estatutario para diferenciarlo del laboral.

Los principios constitucionales rectores de dicho régimen son: el ingreso a la función pública con base en la idoneidad comprobada; la búsqueda de la eficiencia de la Administración Pública y el derecho de estabilidad en el puesto. Por ello, debe garantizarse el acceso de los ciudadanos a los cargos y empleo públicos en condiciones de igualdad y sobre la base de criterios de mérito y capacidad, que constituyen el pilar fundamental del régimen de empleo público.

A pesar de que el artículo 191 constitucional habla de un Estatuto de Servicio Civil, es lo cierto que no restringió dicho concepto al de un instrumento jurídico único, sino que pretende concretar un régimen uniforme de principio y garantías que regulen la protección de los derechos laborales del servidor público especialmente atendiendo al de su derecho a la estabilidad. De ahí que la Contraloría General, El Poder Judicial, las universidades e instituciones autónomas cuentan con su propio estatuto, aunque todos ellos deben enmarcarse dentro de los artículo 191 y 192 constitucionales.

Por otro lado, por regla general prevalecen los principios del Derecho Público sobre el Derecho Laboral o Privado y, de igual manera, corresponde a la Jurisdicción Contencioso Administrativa y Civil de Hacienda conocer las pretensiones en materia de relaciones de empleo público en conformidad con lo establecido en el artículo 3 Código Procesal Contencioso Administrativo y el voto 9928- 2010 de la Sala Constitucional que 
vino a delimitar los ámbitos de competencia de ambas jurisdicciones.

No cabe duda que la jurisprudencia de la Sala Constitucional ha venido a remozar el Estatuto del Servicio Civil sin necesidad de reformas legislativas, al tutelar los derechos de los funcionarios $y$, particularmente, por haber logrado hacer real y efectivo el derecho de estabilidad en el puesto, y en darle estabilidad impropia al servidor interino.

El otro gran aporte consiste en garantizar el derecho de defensa y el debido proceso con lo que ha quedado superada la posibilidad de arbitrariedades en materia disciplinaria.

En fin, la Sala fortaleció y dio vida diaria a los principios constitucionales del régimen.

No obstante, los dos tribunales administrativos del sistema -el Tribunal de Servicio Civil y el Tribunal de Carrera Docente-, deben fortalecerse técnicamente, ya que sus determinaciones comenzarán a ser revisadas en la Jurisdicción Contencioso Administrativa y según sea su solidez técnica y la objetividad en la resolución de los asuntos, serán o no una fortaleza del régimen.

En otro orden de cosas, a pesar de que se han presentado muchos proyectos de ley para reformar de manera integral o sustituir del todo al estatuto, la materia más polémica y álgida es la salarial por las marcadas diferencias que existen dentro del Estado costarricense y en el caso del régimen, por su rigidez ya que la decisión final la adopta el gobierno por medio de la Autoridad Presupuestaria, con lo que la Dirección General de Servicio Civil carece de independencia técnica en esta materia.

Por ello, lo procedente es que se aprueba una nueva ley de salarios que con criterios modernos y realistas, y acorde con el orden jurídico pueda ordenar de una manera más racional la materia salarial
Finalmente, si bien es cierto que el Estatuto de Servicio Civil como cuerpo normativo no se aplica en todo el Estado costarricense, el régimen del servicio civil y las políticas adoptadas por la Dirección General de Servicio Civil, en muchos aspectos orientan la gestión pública y representa el modelo a seguir o, al menos, el modelo del que se debe partir para adoptar decisiones en administración de personal en todo el Estado costarricense.

\section{REFERENCIAS}

Asamblea Legislativa. Expedientelegislativo Decreto No. 1581.

Asamblea Nacional Constituyente de 1949. (1957). Actas T. III San José, Imprenta Nacional.

\section{LEYES}

Ley № 540 del 18 de junio de 1946

\section{VOTOS DE LA SALA CONSTITUCIONAL}

(Base de jurisprudencia de la Sala Constitucional, recuperado el 09-09-2010 de: http://200.91.68.20/scij/

Voto 1119- 1990; Voto 1148- 1990; Voto 50-1991; Voto 17911991; Voto 1837-91; Voto 2231- 1992; Voto 4014- 1993; Voto 5969- 1993; Voto 280- 1994; Voto 927- 1994; Voto 2861 -1994; Voto 4499-1994; Voto 5133- 1994; Voto 5222- 1994; Voto 5227- 1994; Voto 7336- 1994; Voto 2622- 1995; Voto 78- 1996; Voto 227- 1996; Voto 373- 1996; Voto 374- 1996; Voto 1099-1996; Voto 55971996; Voto 3411-1997; Voto 2364-1999; Voto 378- 2000; Voto 668- 2000; Voto 5569- 2000; Voto 8232- 2000; Voto 8406 -2000; Voto 2661- 2001; Voto 2492-2001; Voto 5419- 2001; Voto 12005- 2001; Voto 232 -2002; Voto 1764- 2002; Voto 6057- 2002; Voto 4367- 2003; Voto 26-2004; Voto 831 -2004; Voto 1798 -2004; Voto 12354-2004; Voto 2727- 2004; Voto 5658- 2004; Voto 8742-2005; Voto 10695- 2006; Voto7096-2006; Voto 2423- 2007; Voto 1573- 2008; Voto 15460- 2008; Voto 18206- 2008; Voto 2235- 2009.

\section{VOTOS DE LA SALA SEGUNDA}

Voto 90- 1989; Voto 92-19 89; Voto 169- 1989; Voto 90-1990; Voto 696- 1992; Voto 10653- 2001; Voto 2235- 2009.

Recibido: 26 de octubre de 2010 Aceptado: 20 de febrero 2011 